\title{
Instruments and public policy integration: the network of the Single Registry for Social Programs
}

\author{
Denise do Carmo Direito 12 \\ Natalia Massaco Koga 23 \\ 1 Universidade de Brasília, Brasília / DF - Brazil \\ 2 Ministério da Economia, Brasília / DF - Brazil \\ 3 Instituto de Pesquisa Econômica e Aplicada, Brasília / DF - Brazil
}

This article analyzes the capacity of policy integration through implementation tools. The research builds on studies on policy implementation, which understand such tools as "the state in action," i.e., instruments through which governments operate and deliver public services (Lascoumes \& Le Galès, 2007; Linder \& Peters, 1990). The research examines the case of the Brazilian Single Registry for Social Programs (Cadastro Unnico or CadUnico). The Single Registry is understood as part of a network providing social protection to the Brazilian population in social vulnerability. This work examines CadUnico as a complex system formed of a database and a set of norms and processes that work within the structure of local governments. The system gathers data used to coordinate 20 social programs, helping to select beneficiaries and manage policies that serve 27 million low-income families, reaching almost 80 million people. We adopted the social network analysis as a research method, seeking to answer two main questions: what is the position occupied by the Single Registry in the network of relationships formed by the federal social policies which use it, and what are the conditions and the level of integration which it promotes among these federal user policies? The metrics and sociograms of two distinct timeframes, 2016 and 2018, have demonstrated that, although the Single Register for Social Programs offers elements to promote some integration among public policies, there is no evidence of its effectiveness to this end.

Keywords: Single Registry for Social Programs; policy tool; policy integration; social network analysis (SNA).

\section{Instrumentos e integração de políticas públicas: a rede do Cadastro Único}

Este artigo analisa a capacidade de integração de políticas públicas suportadas por um mesmo instrumento de implementação. Partindo da abordagem dos estudos de implementação de políticas públicas que compreendem os instrumentos como "o estado em ação", isto é, ferramentas de ação pública por meio das quais a ação governamental se materializa e é operacionalizada (Lascoumes \& Le Galès, 2007; Linder \& Peters, 1990), examina-se o caso da Rede do Cadastro Único para Programas Sociais, formada pelo instrumento do Cadastro Único - composto por sua base de dados, normas, processos e estrutura municipal de cadastramento e coleta de dados - e pelos 20 programas sociais que se utilizam de suas informações cadastrais sobre 27 milhões de famílias, quase 80 milhões de pessoas de baixa renda, para seleção de beneficiários e gerenciamento de políticas voltadas ao combate das diferentes formas de vulnerabilidade social. Adotou-se a metodologia da análise de redes sociais para responder a duas perguntas principais: qual é a posição ocupada pelo Cadastro Único (CadÚnico) na rede de relações formada com as políticas sociais que o utilizam e quais são as condições e o nível de integração que o CadÚnico promove entre essas políticas usuárias? As métricas e os sociogramas de dois contextos temporais distintos, 2016 e 2018, demonstraram que, embora haja potencial para que promova maior integração entre as políticas, o CadÚnico ainda não se apresenta como instrumento potente de integração de políticas públicas.

Palavras-chave: Cadastro Único para programas sociais; instrumento de política pública; integração de política pública; análise de redes sociais (ARS). 


\section{Instrumentos e integración de políticas públicas: la red del Registro Único}

Este artículo analiza la capacidad de integración de políticas públicas sustentadas por un mismo instrumento de implementación. Partiendo del enfoque de los estudios de implementación de políticas públicas que comprenden instrumentos como "el estado en acción", es decir, herramientas de acción pública por medio de las cuales la acción gubernamental se materializa y se pone en marcha (Lascoumes \& Le Galès, 2007; Linder \& Peters, 1990), se examina el caso de la Red del Registro Único para Programas Sociales, formada por su base de datos, normas, procesos y estructura municipal de registro y recolección de datos y también por los 20 programas sociales que utilizan la información de registro de 27 millones de familias, casi 80 millones de personas de bajos ingresos, para selección de beneficiarios y gestión de políticas dirigidas al combate de las diferentes formas de vulnerabilidad social. Se adoptó la metodología de Análisis de Redes Sociales para responder a dos preguntas principales: 1) ¿Cuál es la posición que ocupa el Registro Único en la red de relaciones formada con las políticas sociales que lo utilizan? 2) ¿Cuáles son las posibilidades y el nivel de integración que el Registro Único promueve entre esas políticas? Las métricas y sociogramas de dos contextos temporales distintos -2016 y 2018- demostraron que, aunque haya potencial para que promueva una mayor integración entre las políticas, el Registro Único todavía no se presenta como instrumento potente de integración de políticas públicas.

Palabras clave: Registro Único para programas sociales; instrumento de política pública; integración de políticas públicas; análisis de redes sociales (ARS).

\section{INTRODUCTION: ONE INSTRUMENT, MULTIPLE PROGRAMS}

The Single Registry for Social Programs (Cadastro Único) was created by Decree no 6,135 of June 25, 2007 with two main objectives: the identification and socioeconomic characterization of Brazilian low income families and the integration of the federal government's social programs designed to serve the low income population. ${ }^{1}$ In terms of the first aim, we can affirm that the Single Registry played a fundamental role in the rapid expansion of the Bolsa Familia Program, and that slowly over time it has been adopted as the source of beneficiaries for various social programs. However, little is known about its second role: this instrument's capacity for the integration of various public policies.

The Single Registry collects and periodically makes updated information available to 20 federal social programs in respect to the broad profile of socioeconomic information of 27 million families, almost 80 million low income individuals, that is families with income equal to or below minimum wage.

Studies which examine the Single Registry itself as an object of analysis are recent and still scarce, given that in the beginning of its existence it was considered by Bolsa Familia Program studies to be a support instrument in the selection of beneficiaries for the implementation of the program (Direito, Koga, Licio, \& Chaves, 2016, 2018). However, over a period of over a decade, the Single Registry has come to serve and integrate tens of federal programs and a still unknown number of state and municipal programs. This study seeks to describe and explore this new interactional context of the

\footnotetext{
${ }^{1}$ The $2^{\text {nd }}$ and $3^{\text {rd }}$ articles of Decree $n^{\circ} 6,135$ treat the registry as a way to integrate public programs and policies, and for this reason it should be used in a mandatory manner in the selection of beneficiaries. In addition to this, other initiatives, such as the institution of the Single Registry Network in November 2017 sought to "improve the coordination of the federal government'ssocial policies", according to an articleby Agência Brasil retrieved from http://www.brasil.gov.br/cidadania-e-justica/2017/05/cidadaos-tem-acesso-a-dados-do-cadastro-unico-na-nternet?TSPD_101_ $\mathrm{R} 0=54 \mathrm{c} 0 \mathrm{c} 9 \mathrm{e} 659 \mathrm{~d} 528 \mathrm{~d} 85 \mathrm{a} 6868363 \mathrm{~d} 16 \mathrm{~b} 1 \mathrm{bcyA} 800000000000000006 \mathrm{fb} 3 \mathrm{~b} 0 \mathrm{bfffff} 00000000000000000000000000005 \mathrm{~d} 2 \mathrm{e} 335900583$ 22c9208282a9212ab2000a8273c9c90c82c5b32318a8c6a66fb1f66c12533afc86fc42efc6eb876a7dda208d40c58ec0a2800be2aea b10c374d9e27f428ec1ac34eef436a021121544f46b369f9775f7e72e3b7364118305d20b0dessa
} 
Single Registry, analyzing its role as an instrument of integration for public policies, envisaged in its creation, but still not explored in empirical studies.

As an instrument of policy integration, the Single Registry could generate various effects in the policy implementation process, such as the reduction of implementation costs, improved focus, more appropriate offers of social policies, and facilitating citizen access to social benefits (Barca \& Chichir, 2014; Direito et al., 2016). In this study, therefore, we intend to answer two main questions: what is the position occupied by the Single Registry in the network of relationships formed by the federal social policies which use it, and what are the conditions and the level of integration which it promotes among these federal user policies?

As detailed by Direito et al. (2018), the Single Registry instrument is composed of a group of implementation mechanisms, such as norms, municipal customer service posts, data collection and computer system forms. ${ }^{2}$ The present analysis considers the Single Registry to be a collection of these mechanisms, and not just a simple database. We argue that the link between the registry and user programs is not just that of a database. In truth, the other mechanisms mentioned above also condition the implementation of these user programs. For example, the norms of the registry's functioning ${ }^{3}$ have established conditions, structures and processes of functioning which affect the implementation and level of integration of user programs, a reason why they are treated in this study as part of the Single Registry instrument.

\section{REVIEW OF THE LITERATURE}

Our review of the literature explores two theoretical approaches which help us understand the nature of the Single Registry and the complexity of its proper analysis. The first deals with the literature of public policy instruments, justifying the framing of the Single Registry as an instrument of public action, and the relevance of an analysis of its potential as an integration instrument for public policies. The second considers elements of the relational approach to policy implementation to examine the transactional potential of the Single Registry.

\subsection{Public Policy Instruments}

The instruments represent various levels of state intervention and are materialized in distinct forms: norms, regulations, incentives, technical specifications, and tools, among others (Lascoumes \& Le Galès, 2007). As we have seen, the registry represents various of these levels of intervention. To summarize, we can say that it presents norms ${ }^{4}$ and acts in the same inter-federative reality which counts on the development of capacities for the correct filling in of data and performance of registration, as well as the informational system which supports the policy's tasks and materialization.

\footnotetext{
${ }^{2}$ For more information about each of these dimensions of the Single Registry, see Direito et al. (2018).

${ }^{3}$ In addition to Decree $n^{\circ} 6,135 / 07$, which instituted the Single Registry, there is a group of complementary norms, such as Ordinance (Portaria) $\mathrm{n}^{\circ} 501$ of November 29, 2017, which establish a series of conditions and procedures which should be followed when these programs use this data and condition, to some extent, their implementation.

${ }^{4}$ Main norms: Decree no 6,135 of June 26, 2007, and Ordinances n 376 of October 16, 2008 and no 177 of June 16, 2011, as well as operational instructions. Retrieved from http://mds.gov.br/assuntos/cadastro-unico/legislacao\#b_start=0
} 
The various definitions of implementation instruments have the fact that they are identified as "governmental actions" in common. These instruments, therefore, indicate how the state interferes with society and with what objectives. In this way, analyzing them is understanding how the government makes social actors act in a desired manner, given that public policy instruments are governmental initiatives that seek to organize/normalize/encourage or repress certain forms of social behavior.

The analyses of these instruments used to be relegated to a secondary area of public policy studies (Sabatier, 1986). This changed over time, mainly due to studies conducted in the United States (King, 2007; Peters \& Van Nispen, 1998; Salamon, 2002), Canada (Howlett, 2000, 2009), the United Kingdom (Hood, 1983 and 2007) and more recently France (Lascoumes \& Le Galès, 2005, 2007).

Various lessons have been taught based on these analyses. The first, termed "classic" by Brujin and Hufen (1998), was initially related to the mere identification and typification of these instruments. As clarified by Chistopher Hood $(1983,2007)$, a pioneer in this first group of studies, this approach is characterized by the efforts of various theorists to simplify and aggregate instruments as a way to make it possible to understand and note the similarities of the adoption of certain tools for solving public policy issues.

Over several decades, new fronts of analysis formed, such as the instrument-context approach, which considers the contextual characteristics which limit or favor the choice of instrument (Brujin \& Hufen, 1998). In addition to these perspectives, there is the politics of instrumentality approach, which adds a political dimension to the analyses, with the instrument being one of the factors which determine the course of a policy. The focus has broadened to such an extent that it is necessary to understand the political system, considering variables such as the network it belongs to, the arenas of dispute, the implementation process, and equally understanding the ideological reasons or the policy format which lead to the adoption of a given instrument.

Linder and Peters (1990) argue in favor of a fourth approach, termed "constructivist", in which less evident aspects in the use of given instruments need to be analyzed. Thus, symbolic, ethnic, and equality values and perceptions should be considered in terms of the impact of a certain instrument. In this manner, there is no objective reality nor a rational choice, but rather the imperfect knowledge of reality, and the legitimacy of the instrument which is acquired during its use over time (Linder \& Peters, 1990).

The expansion of the analytical scope over time makes it clear that the definition and use of the instrument are not mechanical exercises which "fit into" a well-defined problem and solution. It is the process of constructing the understanding of reality and the attempt to work with this reality. Lascoumes and Le Galès (2005) reinforce the cognitive dimensions of these instruments, in the sense that the choice and use of the instrument demonstrate how the State wishes to intervene in society.

In this article, we will adopt the sociological approach developed by Lascoumes and Le Galès, who understand instruments as tools of public action through which governmental actions are materialized and operationalized (2007). From this perspective, public actions are developed in a socio-political space with ends and objectives - a more functionalist approach - but also authorial projects, or in other words, possible options adopted by actors involved in the moment of definition, considering their values and preferences, as well as the impacts on the society subject to these actions.

Thus, in addition to understanding the reasons which determine the choice of instrument, it is as relevant or more relevant to understand the consequences of these choices on public actions and on the public itself. To Lascoumes and Le Galès (2005), "the instrumentation of public actions is therefore a way to orient relations between political society (via executives/administrators) and civil 
society (via the administrated public) by intermediaries and devices that mix technical (measurements, calculations, rules of law, and procedures) and social components (representations, symbols)".

The analysis of implementation instruments is a way to "unveil" public actions, because they reveal the government's understanding of an issue, and this is why changing the instrument means modifying the objectives or the results that they are seeking to achieve. Instruments are not neutral or adopted using an antiseptic technique. Instead they are selected based on a specific logic and therefore present effects and consequences.

In the specific case of the Single Registry, we seek to analyze its conception and potential as an instrument for integrating public policies. As clarified by Guy Peters (2015), the integration of public policies is a more advanced level of coordination of public policies in which each decision takes into account the effects on all of the organizations and programs associated with it, as well as the consistency of this choice with the common results that they wish to achieve. In other words, the level of integration of public policies requires coherency in its instruments and objectives (Dobuzinskis \& Howlett, 2018; Peters, 2015). This coherence should be reflected ex-ante during the formulation of the programs and instruments and accompanied during the implementation process, guaranteeing that all of the actions will be working in the same direction and that there will be a course correction if the interaction between various actions is generating contradictory effects.

The greatest difficulty in achieving this level of coordination, according to Peters (2015), is that broad public issues - such as social inclusion itself, which is a goal of the Single Registry network can function as facilitating elements for the mobilization and management of organizations and their actions. However, as the author clarifies, the basic issue of coordination is in the balance between the government's specialization and segmentation. Or in other words, what would be the limit of the specialization of public policies which would still enable us to envisage the whole citizen, and not just in a segmented manner, considering just one or more of an individual's facets? The Single Registry appears to be an instrument to deal with this challenge, given that it has the specific goal of offering a wholistic look at social vulnerabilities.

To understand the Single Registry as an integrated instrument of various policies, it is crucial to know its transactional context. This argument will be developed in the two following subsections which will justify the relational approach and the social network analysis method used in this study.

\subsection{The Relational Approach in Public Policy Implementation Studies}

More and more implementation studies have explored less rational and linear analytical approaches, incorporating new explanatory dimensions of this public policy phenomenon as a relational aspect. Emirbayer (1997), one of the first defenders of the relational perspective ${ }^{5}$ for the analysis of social reality,

\footnotetext{
${ }^{5}$ This approach formed through a series of empirical works which focused on transactional aspects and flow dynamics between social entities realized in Europe and the United States. Over the past three or four decades, these studies have gained greater density and have been able to consolidate an analytical perspective with its own assumptions. Despite the different terminology adopted during this time - such as relational as opposed to substantial (Emirbayer, 1997), structural analysis has drawn attention to the form and content of relational structures (Wasserman \& Faust, 1994; Wellman, 1997) and the analysis of social networks which emphasizes the power of the analysis method (Knoke \& Yang, 2008) - this work will use the expression "relational approach" to refer to the group of analytical principles and instruments which involve the field of the exploration of the transactional dimensions among social entities.
} 
points out that the relational approach is opposed to the substantial conception - adopted by currents of thought such as the rational school and normative conformity theories - which understand that social entities are stable, pre-formed and constituted by inherent and immutable attributes. The relational approach by contrast, argues that social entities are in reality a product of the relationships in which they are immersed, and therefore they cannot be analyzed outside of their transactional contexts (Emirbayer, 1997). In this way, the relational approach redefines the unit of analysis which is transferred from an individual and his or her strategies or norms to social relationships. In other words, the point of departure of social action in the relational approach is the transactional context in which social entities are immersed.

These bases for the relational approach can be summarized by three large arguments in the conception of Knoke and Yang (2008). The first is the understanding that in general structural social relations are more powerful resources in explaining social actions than individual attributes, given that we can perceive nuances and changes in various relational contexts which cannot be perceived by observing specific characteristics. The second assumes the understanding that social networks affect perceptions, beliefs and actions through a variety of structural mechanisms constituted by social relationships. Direct contacts and more intense interactions, for example, put entities in better positions in terms of information and influence, while indirect contacts can expose entities to new ideas and resources. Finally, the third assumption is that social relations should be seen as dynamic processes, that is the actions of social entities also transform relational structures which are therefore undergoing constant transformation.

The relational approach recognizes that exchanges between social entities affect the flow of material goods, ideas, information and power, thus determining the constitution of social situations. The universe of the relational field and the position of individuals, therefore is not determined randomly. In truth, they are defined by the possibilities and the limits supplied by their previous paths. In this way, "the relationships and positions in networks constitute relational structures which constrict choices, give differentiated access to goods and instruments of power, making certain alliances or conflicts more or less probable and influencing policy results" (Marques, 2006).

\subsection{The Single Registry Instrument: A Complex System}

The relational approach can aggregate advantages in the analysis of the specific object of this work, the Single Registry, especially if we observe it as a complex system in the sense analyzed by Furtado, Sakowski, and Tóvolli (2015). To the authors, a complex system has three characteristics. First, the sum of the parts which form this system cannot be described by the isolated analysis of each part. Thus, the "whole" is not just more, it is different than the parts (Anderson, 1972 as cited by Furtado et al., 2015). Analyzing the policies which make up the Single Registry systems part by part will not give us a vision of the functioning of the whole.

The second characteristic is that the system does not need central control and can organize itself: there is a synchronization and coordination of policy based on the instruments and the form in which the policy is implemented. Even though the Single Registry is a central node of this network, given that an enormous quantity of information comes out of it and its participation in various policies, there are arrangements between the actors who form new networks and alternative paths, constituting this ecosystem. Thus, it is not appropriate to say that there is central "control".

The third characteristic of complex systems are that they transform over time, or in other words, they adjust to possibilities/impossibilities over the years. Thus, they are adaptive and evolve (Furtado et al., 2015). 
A methodology to manage the challenge of analyzing a system with these characteristics needs to understand the Single Registry beyond its formal structures. It is necessary to explain the form in which the actors and institutions which negotiate and specify the functioning of each part relate, as well as portraying the dynamics of the system, which is more than the simple sum of its parts.

In this way, to understand the role played by the Single Registry, it is crucial to know its transactional context - its composition, flows and dynamics. For this study, the relational approach has the advantage that it is situated in an intermediate plane of analysis which permits the simultaneous observation of its actions and social structures (Marques, 2006). Or in other words, it makes it possible to consider the transaction network of the Single Registry not just in its immediate uses for various social programs, but also for the structures of this group of programs and the Single Registry, as well as a group of actions of all of these entities in the interactional product.

Based on these multiple dimensions and in consonance with the sociological conception of the instruments proposed by Lascoumes and Le Galès $(2005,2007)$, we analyze the instrument of the Single Registry as a complex system in permanent interaction, in the sense of influencing policy actions, policy registration actions and the interaction between the policies that receive information from it.

To understand the integrating role of the Single Registry instrument, this study will explore its transactional context, using the social network analysis method to trace the flow of information and access dynamics and the way this data reaches citizens, making it possible for them to be beneficiaries of these policies.

\section{METHODOLOGY}

The method used in this examination is social network analysis (SNA), which looks for patterns of interaction between social entities (Freeman, 2002; Scott, 1992) and is commonly applied to studies that are based on the relational approach described above.

SNA allows the graphic reproduction of a network analysis of the relationships between the actors and the measurement of their distinct relational characteristics, such as the roles and centrality of the actors, as well as the formation of subgroups in the relational structure. The definitions of the metrics used to explore these characteristics will be detailed in the following section in describing the results of the exploration of each of them.

The data collection was conducted through a semi-structured sociometric survey applied in 29 interviews with managers of the user policies of the Single Registry in March 2016 and June 2018. In 2016, we obtained data for 17 user programs, and in 2018, we obtained data for 20 more. The same survey was applied in the two data collection periods. ${ }^{6}$

\footnotetext{
${ }^{6}$ The following programs were considered in the 2016 and 2018 programs: Rural Technical Assistance; Carteira do Idoso (Elderly ID); Crédito da Reforma Agrária (Agrarian Reform Credit); Facultativo de Baixa Renda (Low Income Social Security Contribution); Fomento às Atividades Rurais (Stimulation of Rural Activities); ID Jovem (Youth ID); Isenção de Taxa de Concurso Público (Exemption of fees for civil service exams); Minha Casa, Minha Vida (My House, My Life); Programa Bolsa Familia (Bolsa Família Program; Programa Cisternas (Cistern Program); Programa de Erradicação do Trabalho Infantil (Eradication of Child Labor Program); Programa Nacional de Crédito Rural (National Program of Rural Credit); Reforma Agrária (Agrarian Reform); Serviço de Fortalecimento de Vínculos (Service of Coexistence and Strengthening of Family Ties); Tarifa de Energia Elétrica (Social Electricity Rates); Telefone Popular (Public Telephone Program); TV Digital (Digital TV). Programs which did not exist or did not use the Single Registry in 2016 which is why they were not considered in the respective sociogram: Ação de distribuição de cestas (Basic food basket distribution); Benefício de Prestação Continuada (BPC), Isenção de taxa de inscrição para o ENEM (Elderly minimum wage benefit, Exemption from a registration fee for the National High School Exam - ENEM); Plano Progredir (Progress Program); Programa Criança Feliz (Happy Child Program). Program discontinued and for this reason it does not appear in the 2018 study: Bolsa Verde (Green Stipend).
} 
The interviewees were asked from whom they receive and to whom they send data/information until they arrive at the "end" user, which would be the government body responsible for the final service or for the concession of a benefit. The frontier of the network constructed in this study was the bodies/institutions which deliver services to citizens. ${ }^{7}$

The information about "who receives information and to whom they send it" was reproduced in a binary matrix in which a 1 identified cases in which there was the sending of information and 0 identified when there was no information sent. The matrix was analyzed using social network analysis (Ucinet and Gelphi) and network visualization software (Netdraw). With this software it was possible to generate sociograms which reproduce the flows of data and information between the managing bodies of federal user programs of the Single Registry and the data sources used to manage the programs - the Single Registry itself, other administrative records or even specific information systems.

The data collection made it possible to map the flow of information established between the Single Registry and the user programs for the concession of social benefits to low income citizens at two distinct times in 2016 and 2018. The longitudinal nature of the study made it possible to compare the networks of 2016 and 2018 to analyze the stability of the relational structure of the Single Registry and the identification of changes in the capacity of the Single Registry to promote the integration of user public policies. Moreover, the comparison between the 2016 network and the 2018 network made it possible to address a critique usually made of the SNA method in terms of its favoring spatiality over temporality given that the method just permits photographs of relational structures. In this case, the comparison between the two photographs allowed us to go beyond a mere descriptive analysis of the relational structure to generate analyses of structural modifications.

\section{RESULTS}

The initial comparison between the 2016 and 2018 networks demonstrated that there was a growth of almost $25 \%$ in the total number of programs which systematically used the Single Registry as an implementation instrument with the entrance of 5 new programs in the network - of these, 2 already existed, but did not use the Single Registry and 3 others were launched during this period.

In relation to the number of nodes, or in other words, actors involved in the treatment of information and policy implementation, the growth was a bit lower: approximately $20 \%$ - from 62 in 2016 to 74 in 2018. In the same way, the number of connections (ties) also grew 20\% - from 145 in 2016 to 174 in 2018. Thus, there was a slightly greater increase in the number of policies in relation to actors, which suggests a simplification of the flows - for example, with the direct transmission of registry information to a program which makes the delivery to citizens - or the optimization and the use of existing structures instead of creating new ones, which demonstrates a greater integration of public policies.

\footnotetext{
${ }^{7}$ This procedure deals with one of the critiques of the SNA method in terms of the relational structure frontiers. Since they are fluid and dynamic, social network frontiers are necessary abstractions which, to some extent, reduce the reproduction of the interactional context. In this study, the delineation of the network frontier analyzed up to the limit of the delivery of benefits to citizens is justified by the study objective of evaluating the capacity of the Single Registry to integrate public policies.
} 
Measures of the network and the nodes will be analyzed below to clarify the level of integration between the registry and the federal social programs.

\subsection{Measures of the Network}

The Single Registry network is composed of nodes (actors), ties and flows of information in which the direction of the ties between the actors matters, indicating who sends information, who only receives it and who sends and receives information, which can limit or facilitate possible paths to access given actors. In this way, measures such as the diameter and the geodesic distance are influenced by this characteristic.

\section{TABLE $1 \quad$ NETWORK MEASUREMENTS}

$\begin{array}{lcc} & \text { 2016 Network } & \text { 2018 Network } \\ \text { Geodesic average } & 4 & 3.4 \\ \text { Density } & 0.038 & 0.032 \\ \text { Diameter } & 10 & 8\end{array}$

Source: Elaborated by the authors.

As mentioned, the data demonstrates that there was growth in the number of programs between the two periods. However, we can perceive from Table 1 that there was a small reduction in density. This measure displays the number of direct links in relation to the total number of possible links. Considering that networks defined as dense are those in which there are a large number of connections and sparse networks are those with few connections, the greater the density, the greater the cohesion of the group (Hatala, 2006).

With the growth of the network, a reduction in density will only not occur if there has been a significant increase in direct links, an increase in the interconnection of actors which did not occur.

The reduction in the diameter also draws out attention. This measure portrays the total number of steps between one end of the network to the other. In the usual terminology of SNA, this is treated as a geodesic - the distance between two nodes - which is longer in this network, considering the shortest route. Thus, the diameter is a graph of the largest geodesic distance among all the pairs of nodes present (Silva, Matheus, Parreiras, \& Parreiras, 2006).

Even though the network "grew", the distance between one point and another was reduced, which may signify the construction of other links which have led to the reduction of the diameter. The geodesic is the average distance between network actors. The measure shows on average how many actors information goes through to reach its final destination. 


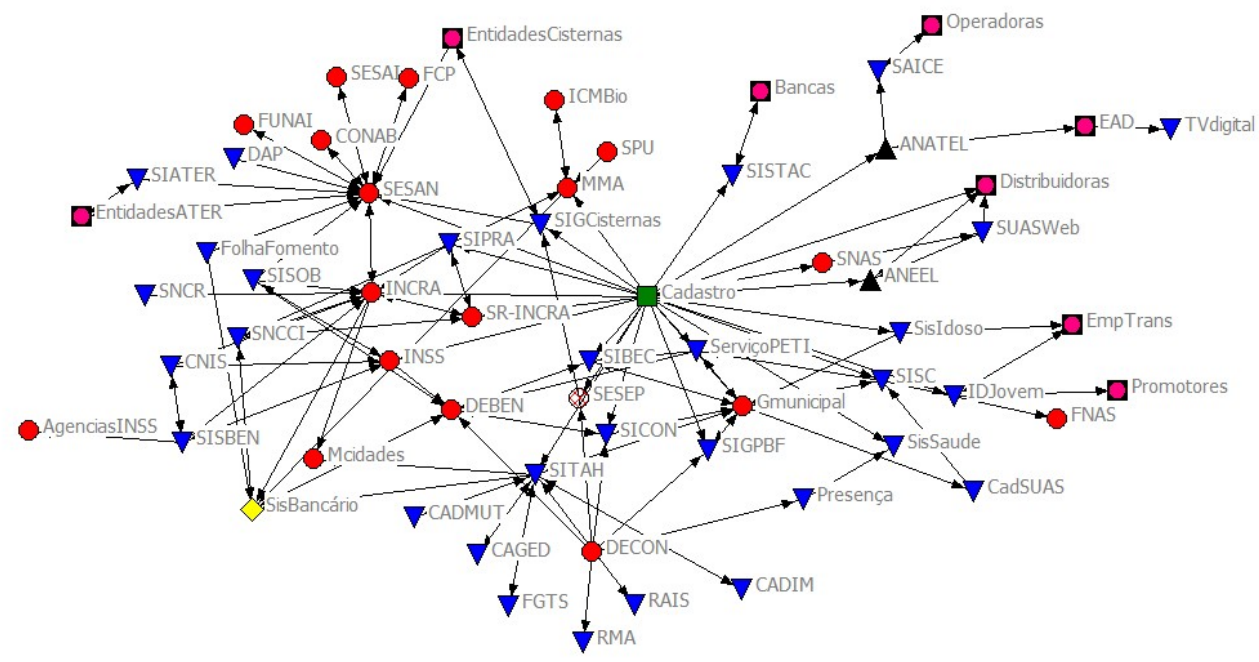

Source: Elaborated by the authors.

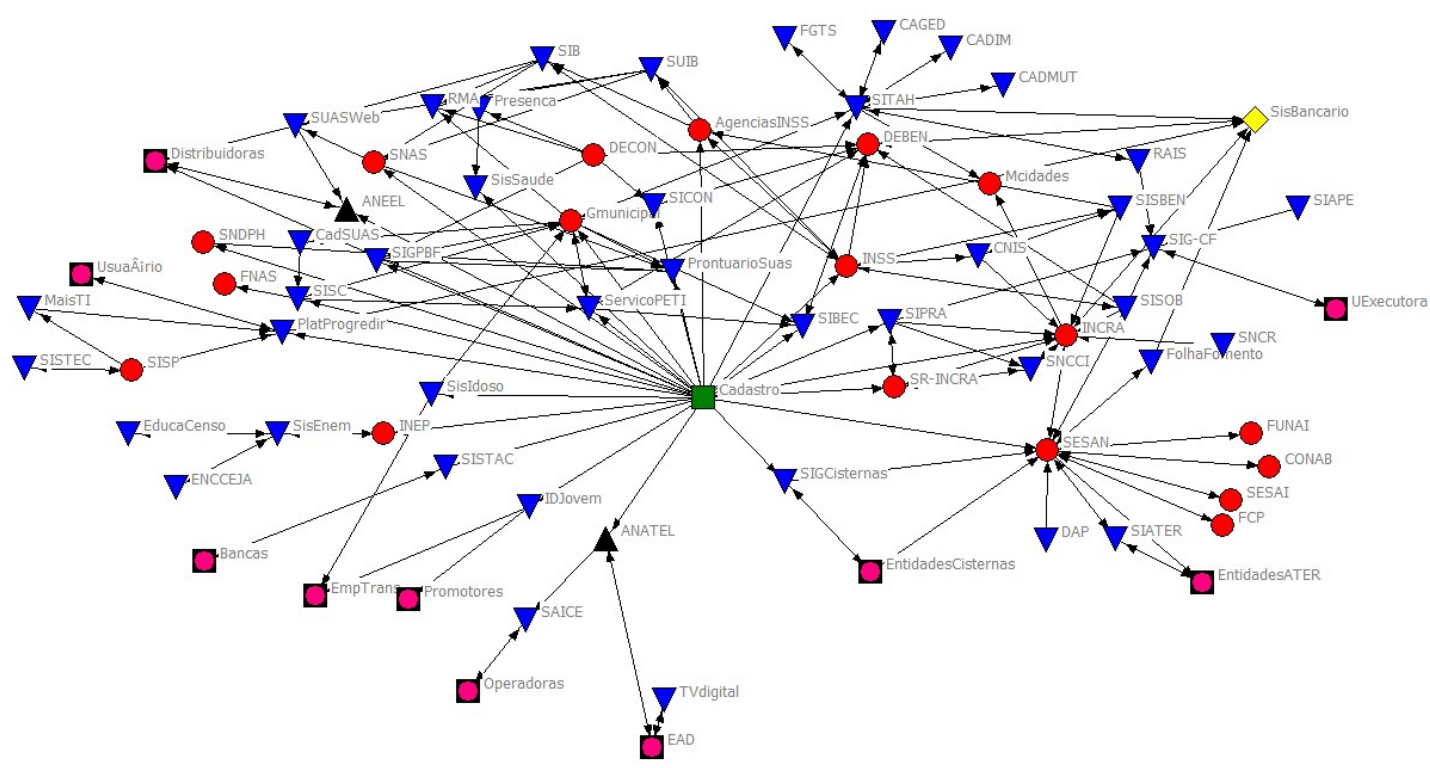

Source: Elaborated by the authors. 
The sociograms demonstrate that most of the contacts that citizens have with social policy providers is, in truth, with no-governmental entities, such as civil servant panels, transport companies, art operators, and banks, etc. The two exceptions are municipal management, which delivers social assistance services, and Social Security branch services (INSS) that operates the BPC, an elderly minimum wage benefit.

As said, a tool with the characteristics of the Single Registry cannot be considered to be exempt from meaning. In addition to the reduction of costs - the same effort to register program users - we should consider the "distance/impersonality" that the central management of these programs now has with the beneficiary public, with a relative loss of power of the program "owners", which is possibly compensated for by more effective management which is less onerous for the public.

\subsection{Node Measurements}

In this section, we will analyze the typical measurements of the nodes (actors). Due to the similarity of the sociograms, we will analyze the network measurements of the Single Registry in 2018. If there is any distinct characteristic of the 2016 network, it will be noted.

The actor is central to a network when it can communicate directly with many others, is close to many actors, or when many actors utilize it as an intermediary in their communications. Actors who have more links with others could be in a more advantageous position. Having many links, they have alternate ways to satisfy needs and take advantage of network resources; thus, they are less dependent than others are (Tomaél \& Marteleto, 2006).

The indegrees and outdegrees are measures which portray the number of connections received or generated by a node. In this way, in directed graphs, a node will be more central to the extent that it has a greater number of received connections (indegrees) or generated connections (outdegrees).

\section{TABLE 2018 NETWORK OUTDEGREES}

\begin{tabular}{l|c} 
Registry & 26 \\
Gmunicipal & 9 \\
Sitah & 8 \\
Sesan & 8 \\
INSS & 7 \\
INCRA & 5 \\
Sisob & 5 \\
Decon & 5 \\
\hline
\end{tabular}

Source: Elaborated by the authors. 


\begin{tabular}{l|l} 
Sesan & 12 \\
INCRA & 10 \\
Deben & 7 \\
Sitah & 7 \\
INSS & 6 \\
Gmunicipal & 6 \\
SIG-CF & 5 \\
Bank System & 5 \\
\hline
\end{tabular}

Source: Elaborated by the authors.

Tables 2 and 3 reproduce the values of the 8 principal actors for each of these measures. A few aspects need to be emphasized. The first is the importance of some actors to certain areas, given that they appear as suppliers of data as well as receivers of information, especially the National Secretariat of Food Security and Nutrition (Sesan), National Institute of Colonization and Agrarian Reform (INCRA), National Institute of Social Security (INSS) and Gmunicipal, with Sesan and INCRA being responsible for programs focused on rural areas - ATER, Fomento (Stimulus), Reforma Agrária (Agrarian Reform), and Crédito Fundiário (Rural Credit) etc. - and Gmunicipal being responsible for the municipal management of social assistance and the delivery of social assistance services.

The Single Registry presents the greatest number of transfers of information - a total of 26 - but does not receive any information. This signifies that the Single Registry being the selection database for all of these programs, transfers information to various other actors - program managers, systems, entities that supply goods/services - but receives none. In this way, it is evident that since it does not receive information, it has limited conditions to be a broker, given its low potential to influence, control or grant access to other nodes in the network.

The restricted influence of the registry becomes more evident when we verify that it is not among the actors with the most betweenness centrality displayed in Table 4. This metric considers actors to be the way to reach other actors, given that it is positioned in the geodesic paths between other pairs of actors in the network. Marteleto (2001) affirms that an actor can have few direct contacts in the network, but it can exercise an important intermediary role by controlling the access of those who circulate in the network and the paths they can travel. 
TABLE 42018 NETWORK BETWEENNESS

\begin{tabular}{lcc} 
& Betweenness & nBetweenness \\
\hline INCRA & 482.1 & $9 \%$ \\
Sesan & 422.5 & $8 \%$ \\
Bank System & 373 & $7 \%$ \\
Sitah & 348.3 & $7 \%$ \\
Gmunicipal & 331 & $6 \%$ \\
SigPBF & 154.5 & $3 \%$ \\
INSS & 142.2 & $3 \%$ \\
Deben & 137.5 & $3 \%$ \\
SUAS & & $2 \%$ \\
Records & 137 & $2 \%$ \\
SNAS & 99 &
\end{tabular}

Source: Elaborated by the Authors.

Besides the actors cited above which effectively have a relevant role in the conduct of policies designed for the rural population and social assistance, some subsystems merit attention, such as the Bank System (SisBancario) and Sitah. The former is the banking system which is involved in the beneficiary payment network (Banco do Brasil, Caixa Econômica Federal and private banks); thus, it receives information from various programs and sends data about withdrawals and payments, but does not articulate policy. In the same manner, Sitah is the name of the system that supports Minha Casa, Minha Vida (My Home, My Life) receiving various forms of information from other databases to verify the veracity of the information provided to the Single Registry. Thus, its role is more of that of a controller and/or auditor than effective transmission or policy articulation.

Clusters are groups of nodes which are strongly linked, because they share characteristics in common or because they are close to each other within the network. The measures of clustering make it possible to identify communities within these networks. In Table 5 the local coefficient has been calculated which expresses an index of "clusterability" of the neighboring nodes in which the maximum point would be interconnectivity with all of the nodes. According to Recupero, Presutti, Consoli, Gangemi, and Nuzzolese (2015), Watts and Strogatz (1998) introduced this metric as a way to determine who forms a small world. 


\begin{tabular}{lc} 
& $n$ Pairs \\
\hline Registry & 325 \\
Sesan & 78 \\
Gmunicipal & 55 \\
INCRA & 55 \\
Sitah & 36 \\
INSS & 28 \\
Deben & 21 \\
PETI Services & 10 \\
SIPRA & 10 \\
INSS Branches & 10 \\
SUAS Records & 10
\end{tabular}

Source: Elaborated by the authors.

In Figure 3, we can perceive from the sociogram that there are groups of programs which share information, forming a denser labyrinth of nodes and lines, which we can characterize as areas of greater public policy integration.

\section{FIGURE 32018 NETWORK SOCIOGRAM - IDENTIFICATION OF GROUPS}

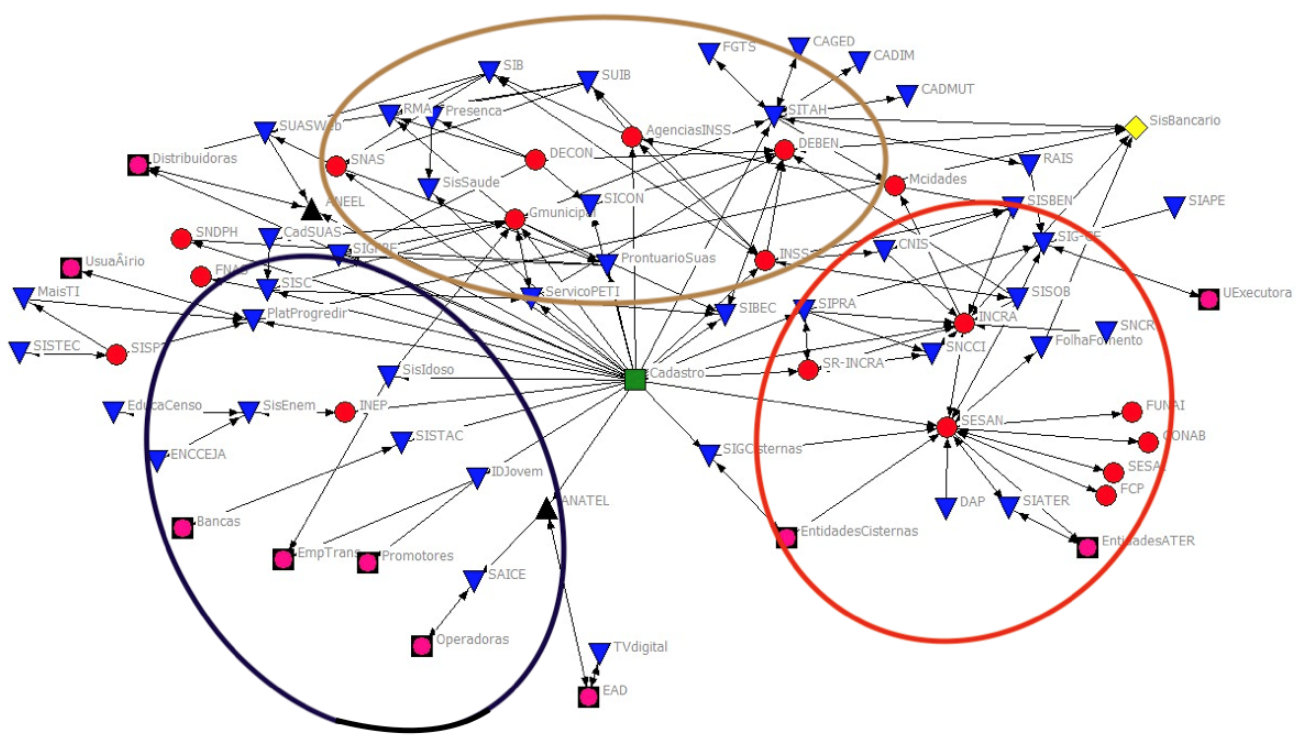

Legend for Group Identification Sociogram

Municipal management - Social assistance

Rural policies

Diverse programs

Source: Elaborated by the authors. 
NetDraw makes it possible to identify the egocentric network of a node. We may perceive that in the measurements of Table 5 some actors acquire prominence, such as Gmunicipal, Sesan and INCRA, with Gmunicipal representing municipal managers responsible for providing information and services - especially related to social assistance - while Sesan and INCRA interact with social policies related to rural areas.

The sociogram analysis of Figure 4 corroborates this by demonstrating the expected role of municipal governments in the Brazilian federal pact, as a point of direct contact with citizens, reinforcing the idea that "municipalities thus become the fundamental managers of social policies in Brazil" (Linhares, Mendes, \& Lassance, 2012); so they are the deliverers of social assistance services. As expected the network presents, in addition to the link with the Single Registry, links with social assistance through systems such as SUAS Records and the SUAS Monthly Customer Service Registry (RMA), which beside social assistance services, also connect to the solicitation and concession systems of the BPC elderly minimum wage benefit (SIB/Suib). SigPBF and Sicon, in turn supply municipal management with information to accompany families which have violated the conditions of the Bolsa Familia program. The connection with Sitah occurs due to part of the selection process of beneficiary families for the Minha Casa, Minha Vida (My Home, My Life) program (band 1) to be executed by municipal assistance managers, via the existing module of the Single Registry itself.

\section{FIGURE 4 SOCIOGRAM OF THE MUNICIPAL MANAGEMENT EGOCENTRIC NETWORK}

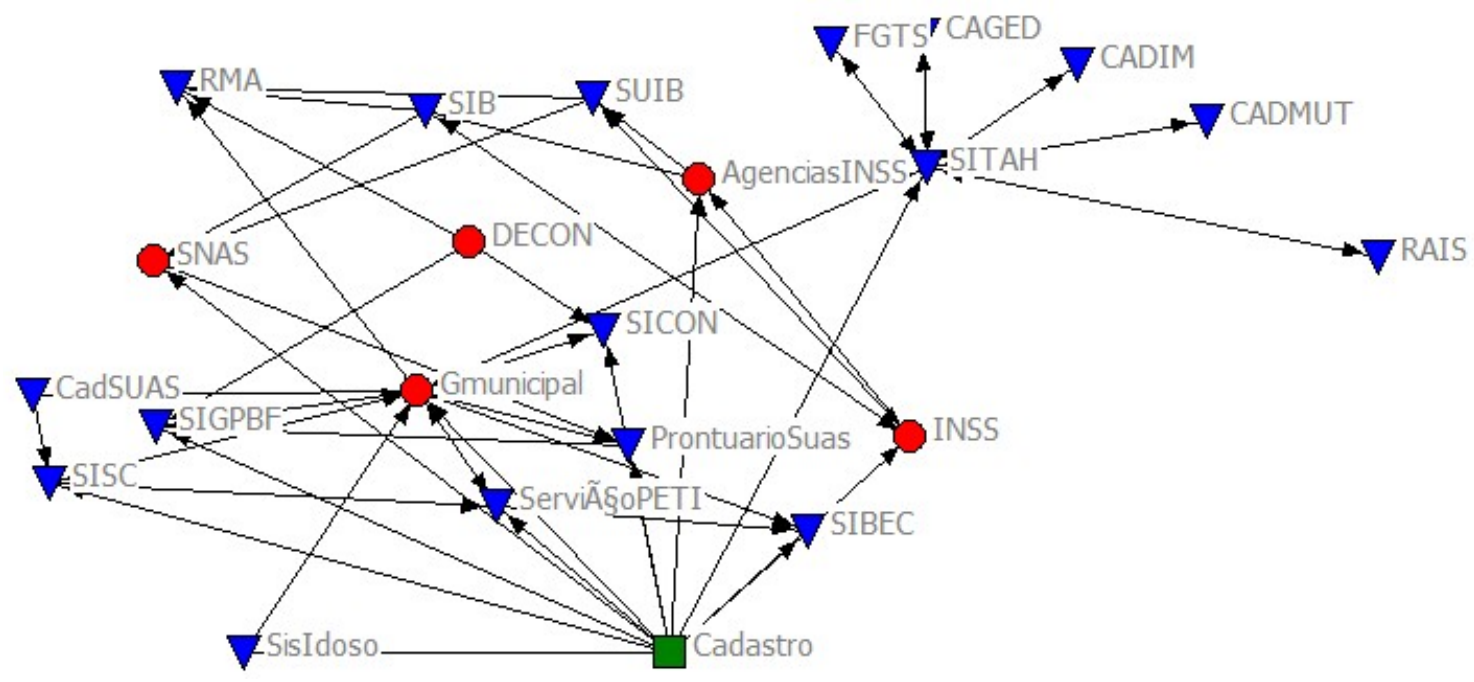

Source: Elaborated by the authors.

Another example of major interaction among nodes is in the group which contains Sesan and INCRA, actors which articulate the entire system of support programs for rural areas, such as Cisterns, the distribution of food baskets, Agrarian Reform, Rural Technical Assistance and Stimulus, as well as credit for settlers. 


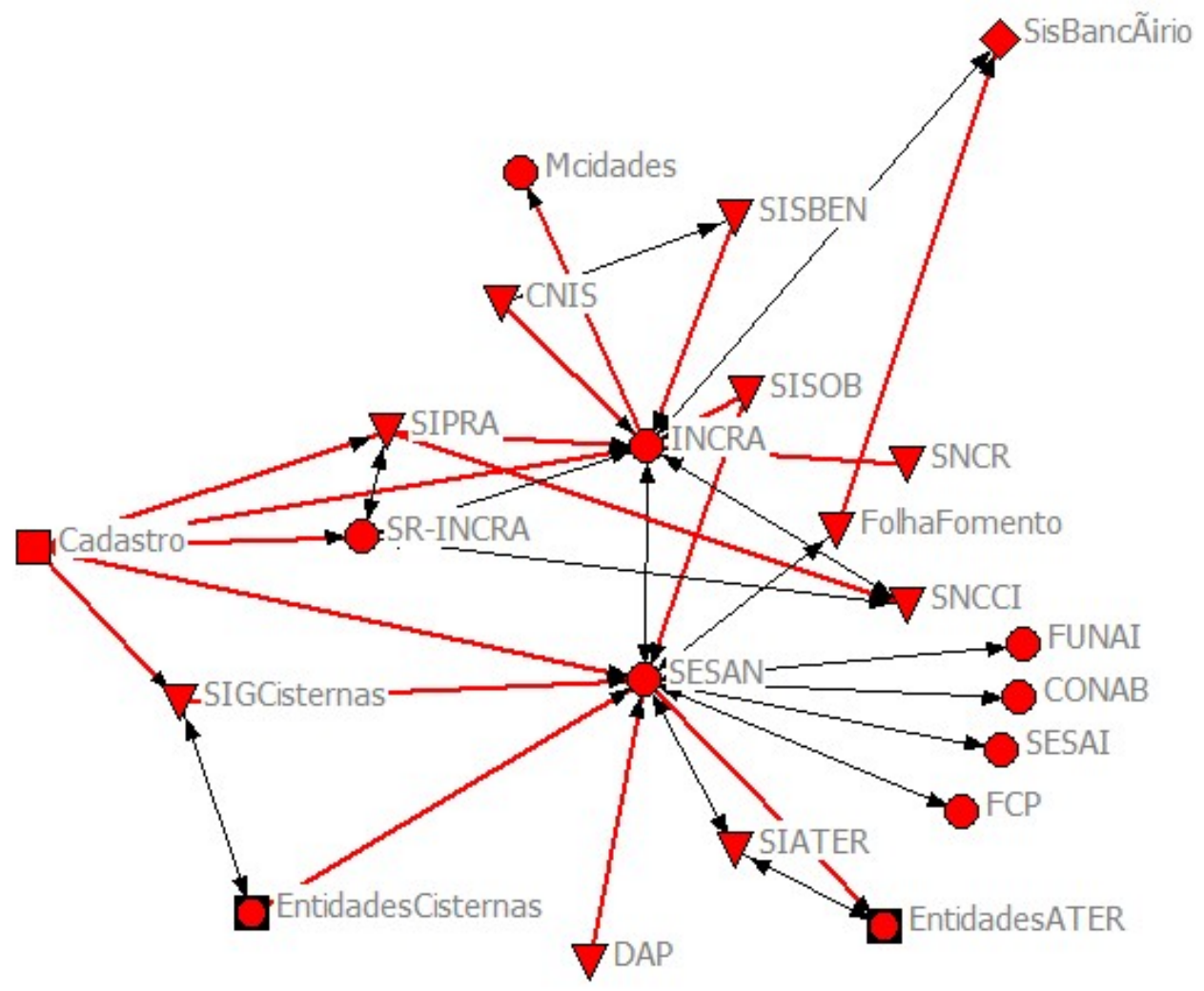

Source: Elaborated by the authors.

For comparison purposes, we can observe the data in the sociogram reproduced in Figure 6, which represents a group of programs with a low degree of interaction between the actors. The sociogram presents lines which extend from the Single Registry node and arrive directly at entities, with the large majority of a private nature, for the supplying of goods or services which is the case of programs such as the Social Electricity Rates, Digital TV, Public Telephones, Progress Program, and Youth ID, etc. They represent simple and direct interactions without intermediaries between the Registry and programs that provide social services and benefits, which in general are private entities. 


\section{FIGURE 6 SOCIOGRAM OF DIVERSE PROGRAMS}

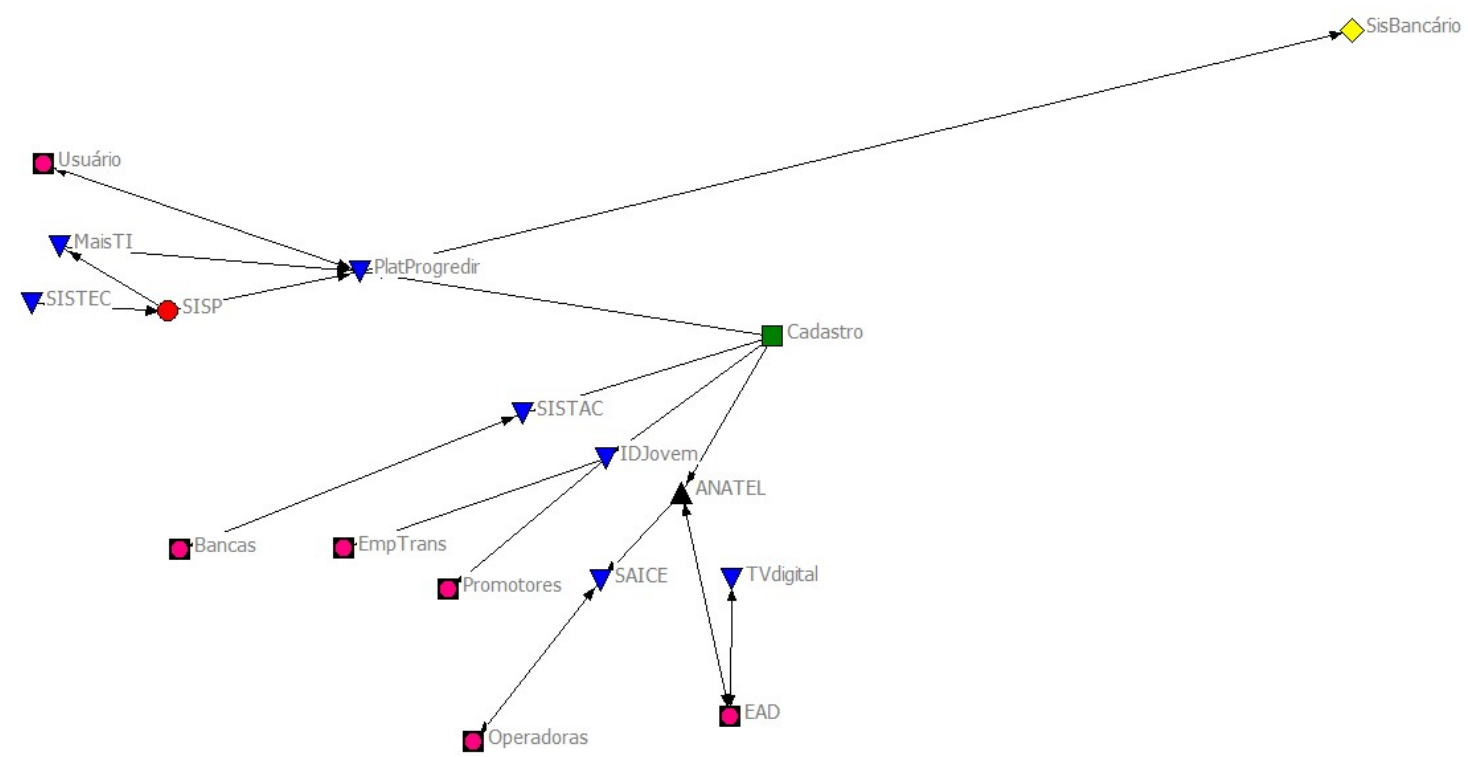

Source: Elaborated by the authors.

\subsection{Program Characteristics from a Relational Perspective}

An analysis of the measures and sociograms enabled the identification of the three main forms of relationships established among the network actors, as can be seen in the box below.

BOX 1

TYPES OF INTERACTIONS IN THE IMPLEMENTATION

\begin{tabular}{|c|c|c|}
\hline Group A (simple interaction) & $\begin{array}{l}\text { Group B (information/intermediary } \\
\text { systems) }\end{array}$ & Group C (complex interactions) \\
\hline Aneel - Social Electricity Rates (TSEE) & SIB/Suib - BPC & $\begin{array}{l}\text { INCRA (Stimulus, ATER, PNRA, Rural } \\
\text { Installation Credit) }\end{array}$ \\
\hline $\begin{array}{l}\text { Anatel (Digital TV and Popular } \\
\text { Telephones) }\end{array}$ & $\begin{array}{l}\text { Sitah (My Home, My Life Management } \\
\text { Program) }\end{array}$ & $\begin{array}{l}\text { Sesan (Distribution of Food Baskets, ATER, } \\
\text { Stimulus, Cisterns) }\end{array}$ \\
\hline $\begin{array}{l}\text { Sistac (Exemption from Fees for Civil } \\
\text { Service Exams) }\end{array}$ & SIGCisterns & $\begin{array}{l}\text { Decon (Conditions for the Bolsa Familia } \\
\text { Program) }\end{array}$ \\
\hline IDJovem (Youth ID) & $\begin{array}{l}\text { PlatProgredir (Progress Program - } \\
\text { Microcredit) }\end{array}$ & $\begin{array}{l}\text { PETI Service (Eradication of Child Labor } \\
\text { Program) }\end{array}$ \\
\hline Sisidoso (Elderly ID) & & $\begin{array}{l}\text { GMunicipal (Receives and transfers money } \\
\text { for customer service provided for public } \\
\text { social assistance services and benefits) }\end{array}$ \\
\hline
\end{tabular}

Source: Elaborated by the authors. 
Grupo A is formed by a group of public policies which have the Single Registry as their main source of information, and have practically no other interface with other systems/programs. Thus, the lines flow in one direction away from the Single Registry until the end of the sociogram. This does not involve, therefore, integrated relationships, since the interactions of these programs extend only in a one-way direction from the Single Registry, that is the registry supplies information to the programs without making integration with other policies viable.

In Group B, the information which is sent out of the registry is "loaded" into other aggregation systems, whose objective is to validate the registry information with data from other databases for beneficiary selection. There is a level of integration promoted by these systems, but there is no form of interaction with other policies. Within this category, the centrality of information systems such as Sitah and SIGCisterns is notable, and both support specific programs. Sitah operationalizes the Minha Casa, Minha Vida (My Home, My Life) program and receives data from various sources, but just presents a single output which makes it possible to manage this program, functioning as an "auditor" of the data supplied to the Single Registry. Meanwhile, SIGCisterns supports the installation of cisterns, sending information to Sesan, which connects to other policies.

Finally, Group C corresponds to the group of policy links with more complex interactions among the actors involved and, therefore, a higher level of integration among the policies involved. This is the case especially of policies devoted to rural areas (Sesan and INCRA) as well as municipal management and the management of Sicon/Decon, which are integrated not only via systems, but also through processes, norms and interactions as managers of social assistance, health and education, in order to verify compliance with the requirements of the Bolsa Familia program.

\section{CONCLUSION}

This analysis of implementation instruments is a way to "unveil" public actions, given that it makes it possible to understand the consequences of these choices in terms of government actions and citizens. This study seeks to explore the choice of the Single Registry as the integration instrument of public policies, and its uses and capacities to truly perform this role. From the state's point of view, our analysis of the relational context of the registry demonstrates various challenges to achieving the goal of policy integration. From society's point of view, one can perceive the implications of the low degree of integration of beneficiary policies.

The metrics and sociograms demonstrate that even though the registry is the main supplier of information for this network, it is practically null in its centrality as a receiver of program and policy data, suggesting that there is no feedback or integration of the data which permits more precise adjustments in terms of family situations, which could improve the implementation of all of these policies. In an equal way, as demonstrated in the sociograms, there is a significant distance between the beneficiaries and the management of most of the programs and the central management of the registry, which also makes a better implementation of these policies inviable.

The data researched and summarized in Box 1 points to the heterogeneity of the levels of integration of the analyzed policies. The registry presents itself as a broker between most of the actors of this network. That is, these actors mostly interact independently of the Single Registry, suggesting that the 
registry is not a potent instrument in the integration of public policies, even though there are cases of more complex interactions in which it makes higher levels of integration between public policies viable.

In this manner, the Single Registry, even though it was created to integrate public policies and is an important conditioning actor to accomplish this, does not by itself have the capacity to guarantee integration. It may be perceived that the policies which were conceived of using a specialization logic, make integration more difficult. In fact, there is little or no recognition of their simultaneous effects on public policies. Moreover, there is no definition of the common targets and objectives which can pave the way to be followed, and there is also no integrated monitoring or evaluation.

In terms of the distinct levels of integration encountered, if the Single Registry did not exist, the possibility of integrating policies would be almost null. However, other conditioning factors are equally relevant, such as institutional coordination arrangements, norms which make common objectives explicit, and the organizational capacities which guarantee the means for integration - for example, teams, equipment, and information systems, etc. The implications of not having a unique ID for citizens should be considered, which makes it difficult to cross-reference data and identify access to various policies. In other words, without the effective identification of the citizen and his or her family, as well as the socioeconomic information that the Single Registry provides, it will be difficult to really integrate the group of policies which address various forms of vulnerability.

This evidence leads to the conclusion that there is potential for integration in the Single Registry network. However, the interaction observed today between the policies is heterogeneous, with cases of practically no relationship with other actors and cases of a high level of interaction in specific fields.

Suggestions for future research include exploring these cases to understand other conditioning factors, in order to promote greater integration between policies, as well as continuity in terms of longitudinal analysis, and seeking to identify other determinant factors for integration, such as political-institutional changes which lead to the birth or death of policies or give more or less centrality to them.

Finally, we suggest studies which explore the limitations of the registry itself, given that a greater permeability in its management of programs and especially of the beneficiaries themselves could lead to great transformations not only in terms of efficiency, but also the effectiveness of these programs in improving the lives of the most vulnerable individuals in Brazil. 


\section{REFERENCES}

Barca, V., \& Chirchir, R. (2014). Single registries and integrated MISs: De-mystifying data and information management concepts. Camberra, Australia: Department of Foreign Affairs and Trade.

Bruijn, J. A., \& Hufen, H. A. M. (1998). The traditional approach to policy instruments. In B. G. Peters, \& F. K. M. V. Nispen. (Eds.), Public policy instruments: Evaluating the tools of public administration. New York, NY: Edward Elgar.

Direito, D., Koga, N., Lício, E., \& Chaves, J. (2016, July). O Cadastro Único como instrumento de articulação de políticas sociais (Working paper número 145). Brasília, DF: Centro Internacional de Políticas para o Crescimento Inclusivo. Retrieved from https:// ipcig.org/pub/port/OP327PT_O_Cadastro_Unico_ como_instrumento_de_articulacao_de_politicas_ sociais.pdf

Direito, D., Koga, N., Lício, E., \& Chaves, J. (2018). As possibilidades e os limites do Cadastro Único como mecanismo de coordenação federativa e de intersetorialidade de políticas públicas. In D. Ximenes. (Org.), Implementação de políticas públicas: questões sistêmicas, federativas e intersetoriais. Brasília, DF: Enap.

Dobuzinskis, L., \& Howlett, M. (Eds.) (2018). Policy analysis in Canada. Bristol, UK: Policy Press.

Emirbayer, M. (1997). Manifesto for a Relational Sociology. The American Journal of Sociology, 103(2), 281-317. Retrieved from https://www.jstor.org/ stable/10.1086/231209

Freeman, L. (2002). The development of social network analysis: a study in sociology of science. North Charleston, SC: Booksurge.

Furtado, B. A., Sakowski, P. A. M., \& Tóvolli, M. (2015). Modelagem de sistemas complexos para políticas públicas. Brasília, DF: Ipea.

Hatala, J. P. (2006). Social network analysis in human resource development: a new methodology. Human Resource Development Review, 5(1), 45-71.

Hood, C. (1983). The tools of Government. London, UK: Macmillan.

Hood, C. (2007). Intellectual obsolescence and intellectual makeovers: Reflections on the tools of government after two decades. Governance, 20(1), 127-144.
Howlett, M. (2000). Managing the "hollow state": Procedural policy instruments and modern governance. Canadian Public Administration, 43(4), 412-431.

Howlett, M. (2009). Governance modes, policy regimes and operational plans: A multi-level nested model of policy instrument choice and policy design. Policy Sciences, 42(1), 73-89.

King, D. (2007). The American State and Social Engineering Policy Instruments in Affirmative Action. Governance, 20, 109-126.

Knoke, D., \& Yang, S. (2008). Social network analysis. London, UK: Sage Publications.

Lascoumes, P., \& Le Galès, P. (2005). Gouverner par les instruments. Paris, France: Presses de Sciences Po.

Lascoumes, P., \& Le Galès, P. (2007). Introduction: understanding public policy through its instruments-from the nature of instruments to the sociology of public policy instrumentation. Governance, 20, 1-21.

Linder, S., \& Peter, G. (1990). The Design of Instruments for Public Policy. In N. Westport. (Ed.), Policy Theory and Policy Evaluation. Westport, CO: Greenwood Press.

Linhares, P. T. F., Mendes, C. C., \& Lassance, A. (2012). Federalismo à brasileira: questões para discussão. Brasília, DF: Ipea.

Marques, E. C. (2006). Redes sociais e poder no estado brasileiro: aprendizado a partir das políticas urbanas. Revista Brasileira de Ciências Sociais, 21(60), 15-41.

Marteleto, R. (2001). Análise de redes sociais: aplicação nos estudos de transferência da informação. Ciência da Informação, 30(1), 71-81.

Peters, B. G. (2015). Pursuing horizontal management: The politics of public sector coordination. Kansas, KS: University Press of Kansas.

Peters, B. G., \& Nispen, F. K. M. van (Eds). (1998). Public policy instrumentes: Evaluating the tools of public administration. Nova York, NY: Edward Elgar.

Recupero, D. R., Presutti, V., Consoli, S., Gangemi, A., \& Nuzzolese, A. G. (2015). Sentilo: frame-based sentiment analysis. Cognitive Computation, 7(2), 211-225. 
Sabatier, P. A. (1986). Top-Down and Bottom-up approaches to implementation research: a critical analysis and suggested synthesis. Journal of Public Policy, 6(1), 21- 48.

Salamon, L. (2002). The Tools of Government: A Guide to the New Governance. New York, NY: Oxford University Press.

Scott, J. (1992). Social network analysis. Newbury Park, CA: Sage Publications.

Silva, A., Matheus, R., Parreiras, F., \& Parreiras, T. (2006). Análise de redes sociais como metodologia de apoio para a discussão de interdisciplinaridade na ciência da informação. Retrieved from www.scielo. br/pdf/ci/v35n1/v35n1a09
Tomaél, M. I., \& Marteleto, R. M. (2006). Redes sociais: posições dos atores no fluxo da informação. Encontros Bibli - Revista Eletrônica de Biblioteconomia e Ciência da Informação, 11(1), 75-91.

Wasserman, S., \& Faust, K. (1994). Social network analysis: Methods and applications. Cambridge, UK: Cambridge University Press.

Watts, D. J., \& Strogatz, S. H. (1998). Collective dynamics of 'small-world'networks. Nature, 393(6684), 440-442.

Wellman, B. (1997). Structural analysis: From method and metaphor to theory and substance. Contemporary Studies in Sociology, 15, 19-61.

\section{Denise do Carmo Direito}

https://orcid.org/0000-0002-2323-2846

Ph.D. Student in Political Science at the University of Brasilia (UnB) in Politics and Institutions; Master's in Political Science from the University of Brasilia (UnB) in Democracy and Society; Specialist in the Career of Public Policy and Governmental Management since 2002. E-mail: denisedireito.dd@gmail.com

\section{Natalia Massaco Koga}

https://orcid.org/0000-0003-0143-8373

Ph.D. in Political Science from the University of Westminster, United Kingdom; Researcher in the Directorate of State Studies and Policies of Institutions and Democracy (Diest) of the Institute of Economic and Applied Research (IPEA); Specialist in the Career of Public Policy and Governmental Management; Professor for the Professional Master's Degree in Governance and Development at the National School of Public Administration (ENAP). E-mail: natmkoga@gmail.com 